\title{
Pemulsaan dan Ameliorasi Tanah Salin untuk Pertumbuhan dan Hasil Kedelai
}

\section{Mulching and Amelioration Saline Soil for Growth and Yield of Soybean}

\author{
Runik Dyah Purwaningrahayu* dan Abdullah Taufiq
}

Balai Penelitian Tanaman Aneka Kacang dan Umbi

J1. Raya Kendalpayak Km. 8, PO. Box 66 Malang 65101, Indonesia

Diterima 17 November 2017/Disetujui 3 Juli 2018

\begin{abstract}
Most salt-affected agricultural land has low productivity such that suitable management is required to improve the productivity. Negative effect of salinity stress can be reduced by growing salt-tolerant cultivars and soil amelioration. The objective of the research was to identify effective ameliorant and effect of mulching in improving soybean growth and yield on saline soil. The research was conducted on saline soil in Lamongan District that has electrical conductivity (EC) of 11.39 $d S \mathrm{~m}^{-1}$ during dry season 2016. Treatments consists of two factors that were arranged in split plot design, and replicated three times. The main plot was mulching, i.e. without mulching and mulching with 3.5 ton ha ${ }^{-1}$ rice straw. The subplots were six amelioration traits, namely without amelioration (control), $120 \mathrm{~kg} \mathrm{ha}^{-1} \mathrm{~K}_{2} \mathrm{O}, 750 \mathrm{~kg} \mathrm{ha}^{-1} \mathrm{~S}, 5$ ton ha-1 $\mathrm{gypsum}^{-5}$ ton ha${ }^{1}$ manure and combination of 5 ton ha ${ }^{-1}$ manure +1.5 ton ha $a^{-1}$ gypsum. The soybean seed used was $K-13$, a saline tolerant genotipe. The results showed that mulching reduced soil EC, increased $K$ and Ca absorption, leaf chlorophyll index, improved growth and yield. Soil amelioration with $\mathrm{K}_{2} \mathrm{O}$, sulphur, gypsum, or combination of manure+gypsum decreased soil EC and soil $\mathrm{pH}$. Amelioration with gypsum increased the grain yield of $36.3 \%$.
\end{abstract}

Keywords: EC, leaf chlorophyl index, salinity stress, soil management

\section{ABSTRAK}

Lahan pertanian di Indonesia yang terpengaruh garam semakin luas dengan produktivitas rendah, sehingga memerlukan pengelolaan untuk meningkatkan produktivitasnya. Pengaruh negatif cekaman salinitas dapat dikurangi dengan menanam genotip toleran salinitas dan ameliorasi tanah. Tujuan penelitian adalah untuk mengidentifikasi bahan amelioran yang efektif serta keefektifan pemulsaan dalam memperbaiki pertumbuhan dan hasil kedelai di tanah salin. Penelitian dilaksanakan pada

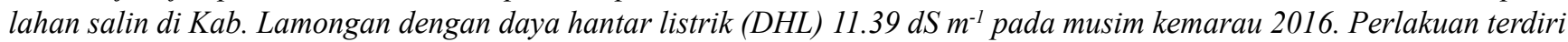
atas dua faktor, disusun dalam rancangan petak terbagi, diulang tiga kali. Petak utama adalah pemulsaan (tanpa mulsa dan dengan mulsa jerami 3.5 ton $\mathrm{ha}^{-1}$ ). Anak petak adalah enam macam ameliorasi tanah, yaitu tanpa ameliorasi (kontrol), $120 \mathrm{~kg} \mathrm{ha}^{-1} \mathrm{~K}_{2} \mathrm{O}, 750 \mathrm{~kg} \mathrm{ha}^{-1} \mathrm{~S}, 5$ ton hat gipsum, 5 ton ha $\mathrm{a}^{-1}$ pupuk kandang, dan kombinasi 5 ton ha pupuk kandang + 1.5 ton ha $\mathrm{a}^{-1}$ gipsum. Benih kedelai yang digunakan adalah galur K-13 yang toleran salin. Hasil penelitian menunjukkan bahwa penggunaan mulsa berpeluang menurunkan DHL tanah, meningkatkan penyerapan unsur $K$ dan Ca, meningkatkan indeks kandungan klorofil, memperbaiki pertumbuhan dan meningkatkan hasil kedelai yang toleran salin. Ameliorasi tanah berkadar salinitas tinggi menggunakan $\mathrm{K}_{2} \mathrm{O}$, belerang $(S)$, gipsum maupun kombinasi pupuk kandang + gipsum dapat menurunkan DHL dan pH tanah. Ameliorasi dengan gipsum dapat meningkatkan hasil biji hingga 36.3\%.

Kata kunci: cekaman salinitas, DHL, indeks kandungan klorofil, pengelolaan tanah

\section{PENDAHULUAN}

Lahan pertanian di Indonesia yang mengalami masalah salinitas diperkirakan 0.44 juta hektar (Alihamsyah et al., 2002). Peningkatan salinitas lahan sawah irigasi di sepanjang pantai utara Pulau Jawa (Indramayu) menyebabkan produksi padi turun (Erfandi dan Rachman, 2011), juga lahan sawah

\footnotetext{
* Penulis untuk korespondensi. e-mail: runik_dpr@yahoo.com
}

di Aceh akibat tsunami tahun 2004 (Rachman et al., 2008b). Peningkatan salinitas lahan pertanian tersebut mengancam stabilitas produksi pertanian, terutama tanaman pangan. Hal ini karena sebagian besar tanaman budidaya sangat peka terhadap salinitas (Dogar et al., 2012).

Pemanfaatan lahan salin dapat ditingkatkan melalui penggunaan genotipe toleran dan pengelolaan tanah yang sesuai. Tanaman kedelai peka terhadap salinitas, tetapi kepekaannya beragam antar genotipe (Golezani et al., 2011). Genotipe MLG 2510 toleran pada kadar salinitas $0.4 \% \mathrm{NaCl}$ 
atau DHL $6 \mathrm{dS} \mathrm{m}^{-1}$ (Sunarto, 2001), genotipe IAC100/Bur/ Malabar-10-KP-21-50 dan K-13 toleran hingga DHL 12.2 $\mathrm{dS} \mathrm{m} \mathrm{m}^{-1}$ (Purwaningrahayu et al., 2015).

Pencucian (leaching) merupakan cara paling efektif menurunkan kadar garam, tetapi membutuhkan air segar yang banyak, dan waktu lama. Alternatif lain adalah penambahan bahan amelioran untuk meminimalkan pengaruh buruk unsur Na. Aplikasi pupuk K efektif mengurangi efek toksik unsur $\mathrm{Na}$ (Kopittke, 2012). Aplikasi gipsum (Joachim dan Verplancke, 2010), kompos dan gipsum (Kahlon et al., 2012; Murtaza et al., 2013) efektif untuk ameliorasi tanah salin. Unsur S meningkatkan toleransi tanaman terhadap salinitas (Nazar et al., 2011). Kompos dan besi sulfat efektif menurunkan $\mathrm{pH}$, salinitas, dan sodisitas tanah salin (Mahdy, 2011a).

Pemulsaan menurunkan evapotranspirasi dan akumulasi garam ke permukaan(Zhang et al., 2008), menjaga kelembaban tanah di daerah perakaran, menurunkan suhu tanah, evaporasi, dan akumulasi garam (Abou-Baker et al., 2011; Swarup, 2013; Alharbi, 2015). Pemulsaan mengurangi efek negatif salinitas pada tanaman kapas (Dong, 2012).

Tujuan penelitian adalah mendapatkan amelioran yang efektif untuk ameliorasi tanah salin serta keefektifan penggunaan mulsa guna memperbaiki pertumbuhan dan hasil kedelai pada tanah salin.

\section{BAHAN DAN METODE}

Penelitian dilaksanakan pada lahan sawah tadah hujan di Desa Lohgung, Kec. Brondong, Kab. Lamongan (653'59.89801" S; 112 111'15.3127” E, $26 \mathrm{~m} \mathrm{dpl)} \mathrm{selama}$ Mei-Agustus 2016, menggunakan galur K-13 (toleran salin). Kedelai galur K-13 merupakan hasil persilangan yang dilakukan pemulia tanaman Balai Penelitian Tanaman Aneka Kacang dan Umbi (Balitkabi) untuk menghasilkan varietas kedelai toleran penyakit karat. Galur K-13 atau Argopuro//IAC100 juga teridentifikasi toleran salinitas hingga DHL $15.6 \mathrm{dSm}^{-1}$ pada percobaan di rumah kaca (Purwaningrahayu dan Taufiq, 2017). Karakteristik tanah lokasi penelitian adalah DHL $11.39 \mathrm{dS} \mathrm{m} \mathrm{m}^{-1}, \mathrm{pH}$ 7.5, Corganik $1.16 \%$, K-dd $0.89 \mathrm{cmol}^{+} \mathrm{kg}^{-1}, \mathrm{Na}$-dd $2.37 \mathrm{cmol}^{+}$ $\mathrm{kg}^{-1}$, Ca-dd $16.70 \mathrm{cmol}^{+} \mathrm{kg}^{-1}, \mathrm{Mg}$-dd $14.70 \mathrm{cmol}^{+} \mathrm{kg}^{-1}$, dan kejenuhan $\mathrm{Na} 6 \%$.

Percobaan dilaksanakan dalam rancangan petak terbagi, diulang tiga kali. Petak utama terdiri atas dua pemulsaan, yaitu tanpa mulsa (M0) dan dengan mulsa jerami 3.5 ton ha $^{-1}$ setara kering (M1). Anak petak terdiri atas enam macam amelioran, yaitu kontrol (P0), $120 \mathrm{~kg} \mathrm{ha}^{-1} \mathrm{~K}_{2} \mathrm{O}(\mathrm{P} 1)$, $750 \mathrm{~kg} \mathrm{ha}^{-1}$ belerang (S) (P2), 5 ton ha- ${ }^{-1}$ gipsum (P3), 5 ton $\mathrm{ha}^{-1}$ pupuk kandang (P4), dan kombinasi 5 ton $\mathrm{ha}^{-1}$ pupuk kandang +1.5 ton $\mathrm{ha}^{-1}$ gipsum (P5). Pemberian amelioran dan pemulsaan dengan cara disebar sesaat setelah tanam.

Pengolahan tanah dengan rotary. Ukuran plot $4 \mathrm{~m}$ x $3 \mathrm{~m}$, antar plot dipisahkan dengan saluran drainase. Benih ditanam dengan cara tugal, jarak tanam $40 \mathrm{~cm} \mathrm{x}$ $15 \mathrm{~cm}, 2-3$ biji per lubang, kemudian pada umur 15 hari setelah tanam (HST) dilakukan penjarangan menjadi dua tanaman per rumpun. Setelah tanam dilakukan penyiraman menggunakan air sumur (DHL $3.88 \mathrm{dS} \mathrm{m}^{-1}$ ), dan setelah itu tidak diairi karena curah hujan cukup. Penyiangan manual dilakukan saat $20 \mathrm{HST}$ dan $40 \mathrm{HST}$. Pupuk dasar $75 \mathrm{~kg}$ $\mathrm{ha}^{-1}$ urea, $100 \mathrm{~kg} \mathrm{ha}^{-1} \mathrm{SP} 36$, dan $50 \mathrm{~kg} \mathrm{ha}^{-1} \mathrm{KCl}$ diberikan saat tanam dengan cara disebar dalam barisan tanaman. Pengendalian hama dan penyakit menggunakan pestisida kimia. Panen dilakukan umur 83 HST ketika sebagian besar polong sudah tua.

Pengamatan terdiri atas daya tumbuh benih saat 15 HST, biomas tajuk saat 50 HST, dan karakteristik kimia tanah saat panen. Contoh tanah saat panen diambil secara komposit dari setiap plot pada kedalaman 0-20 cm. Penetapan kadar air tanah dengan metode gravimetric, pengukuran DHL menggunakan Portable EC meter, dan pengukuran tinggi tanaman dengan meteran. Penetapan Indeks Kandungan klorofil menggunakan Chlorophylmeter SPAD 502 saat tanaman berumur 15, 30, 45, 60, dan 75 HST. Analisis kandungan hara jaringan tanaman $(\mathrm{Na}, \mathrm{Ca}, \mathrm{Mg}$, dan $\mathrm{K}$ ) dilakukan saat pertumbuhan vegetatif maksimum (45 HST). Pengamatan saat panen meliputi jumlah tanaman panen, bobot kering brangkasan, tinggi tanaman, jumlah polong isi, bobot biji kering, dan bobot 100 biji.

\section{HASIL DAN PEMBAHASAN}

\section{Pertumbuhan Tanaman}

Salinitas tanah saat tanam sangat tinggi, yang diindikasikan oleh tingginya DHL tanah, tetapi benih kedelai galur K-13 yang ditanam pada penelitian ini berdaya tumbuh $95-97 \%$ (Tabel 1). Hal ini menunjukkan bahwa galur tersebut tahan terhadap cekaman salinitas tinggi selama fase perkecambahan. Pemulsaan dan pemberian bahan amelioran serta interaksi keduanya tidak berpengaruh terhadap daya tumbuh benih, biomas tajuk 50 HST, dan tinggi tanaman; kecuali pengaruh nyata mulsa terhadap tinggi tanaman umur 15 HST (Tabel 1). Tanaman tumbuh lebih tinggi pada umur 15 HST akibat pemulsaan dibandingkan tanpa mulsa karena penggunaan mulsa jerami padi dengan cara disebar secara merata di permukaan tanah dapat mengurangi penguapan tanah sehingga meningkatkan kelembaban tanah, selanjutnya mengurangi cekaman kekeringan fisiologis seperti yang sering terjadi pada tanah salin. Jerami padi juga dapat meningkatkan ketersediaan hara makro apabila telah terdekomposisi.

Pertumbuhan tanaman yang cenderung lebih baik pada perlakuan pemulsaan karena DHL tanah yang lebih rendah serta ketersediaan air (KA) yang lebih tinggi (Gambar 1A). Hal ini mungkin berkaitan dengan menurunnya evaporasi sehingga menghambat akumulasi garam pada lapisan tanah atas. Abou-Baker et al. (2011), Swarup (2013), dan Alharbi (2015) menyatakan bahwa pemulsaan menurunkan laju evaporasi dan akumulasi garam pada lapisan atas.

Dengan pemberian amelioran pertumbuhan tanaman relatif baik (Tabel 1) ini kemungkinan karena DHL dan $\mathrm{pH}$ tanah yang cenderung lebih rendah. DHL tanah akibat pemberian berbagai bahan amelioran cenderung lebih rendah dibandingkan tanpa pemberian amelioran (Gambar 1B). Penambahan amelioran belerang (S), gipsum, dan kombinasi pupuk kandang + gipsum cenderung menurunkan 
Tabel 1. Persentase daya kecambah, tinggi tanaman, dan biomas tajuk tanaman kedelai galur K-13 pada tanah salin akibat pemulsaan dan pemberian amelioran

\begin{tabular}{lcccc}
\hline Perlakuan & Daya tumbuh $(\%)$ & $\begin{array}{c}\text { Tinggi tanaman } \\
\text { 15 HST }(\mathrm{cm})\end{array}$ & $\begin{array}{c}\text { Biomas tajuk 50 HST } \\
(\mathrm{g} \text { per tanaman })\end{array}$ & $\begin{array}{c}\text { Biomas tajuk saat } \\
\text { panen }(\text { ton ha })^{-1}\end{array}$ \\
\hline $\begin{array}{l}\text { Mulsa } \\
\text { Tanpa mulsa }\end{array}$ & 96.42 & $9.1 \mathrm{~b}$ & 6.69 & 0.91 \\
$\quad$ Mulsa & 96.33 & $10.1 \mathrm{a}$ & 7.17 & $1.17(28.6)^{1)}$ \\
Ameliorasi & & & \\
Kontrol & 97.08 & 9.6 & 7.32 & 0.99 \\
K ${ }_{2}$ & 97.33 & 9.5 & 7.49 & $1.13(14.1)$ \\
S & 96.33 & 9.7 & 6.73 & 0.99 \\
Gipsum & 95.08 & 9.5 & 6.38 & $1.08(9.1)$ \\
Pupuk kandang & 95.75 & 9.7 & 7.31 & 0.94 \\
Pukan+Gipsum & 96.67 & 9.7 & 7.35 & $1.06(7.1)$ \\
\hline
\end{tabular}

Keterangan: Angka dengan huruf yang sama atau tanpa didampingi huruf pada kolom di masing-masing kelompok perlakuan menunjukkan tidak berbeda nyata dengan uji BNT taraf $5 \% ;{ }^{1)}$ angka dalam kurung adalah persentase peningkatan terhadap tanpa mulsa dan tanpa ameliorasi

pH tanah 0.1-0.3 unit dibandingkan kontrol, baik dengan pemulsaan maupun tanpa mulsa (Tabel 2). Penurunan $\mathrm{pH}$ akibat ameliorasi dengan belerang cenderung lebih tinggi dibandingkan yang menggunakan gipsum maupun kombinasi pupuk kandang+gipsum. Gharaibeh et al. ( 2011) menunjukkan bahwa belerang, gipsum, dan pupuk kandang efektif menurunkan DHL tanah. Belerang dan gipsum efektif menurunkan $\mathrm{pH}$ tanah salin (Nazar et al., 2011). Bahan organik mempercepat pencucian $\mathrm{Na}^{+}$dan menurunkan DHL tanah salin karena kemampuannya meningkatkan infiltrasi dan stabilitas agregat tanah, kemampuan menyimpan air dan mengurangi penguapan (Mahdy, 2011b; Tazeh et al., 2013; Rachman et al., 2008a). Penelitian pada tanaman Calopogonium muconoides, menunjukkan efektivitas gipsum yang meningkat bila dikombinasikan dengan bahan organik (Kusmiyati et al., 2014).

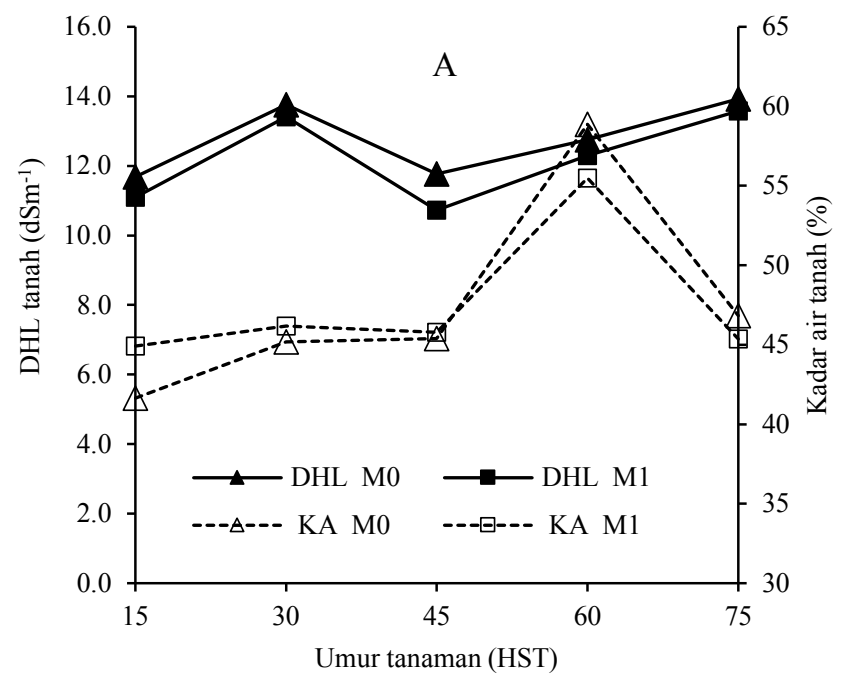

\section{Indeks Kandungan Klorofil (IKK)}

Perlakuan pemulsaan dan ameliorasi, serta interaksi keduanya tidak berpengaruh nyata terhadap IKK daun, kecuali pengaruh interaksi terhadap IKK saat tanaman berumur $75 \mathrm{HST}$. IKK cenderung makin turun dengan meningkatnya umur tanaman, dan penurunan makin drastis saat tanaman berumur $60 \mathrm{HST}$ hingga $75 \mathrm{HST}$, yaitu saat fase pengisian polong. Selain dikarenakan pengisian polong, penurunan IKK daun dapat mengindikasikan terjadinya degradasi klorofil. Secara visual tanaman kedelai di tanah salin Lamongan mengalami klorosis ringan hingga sedang, tetapi yang mencolok adalah perbedaan durasi umur daun. Pada tanaman dengan perlakuan mulsa, daun lebih hijau, dan tidak cepat gugur. Sebaliknya, daun cepat menguning dan gugur bila tanpa mulsa. Hal ini juga terlihat dari IKK daun

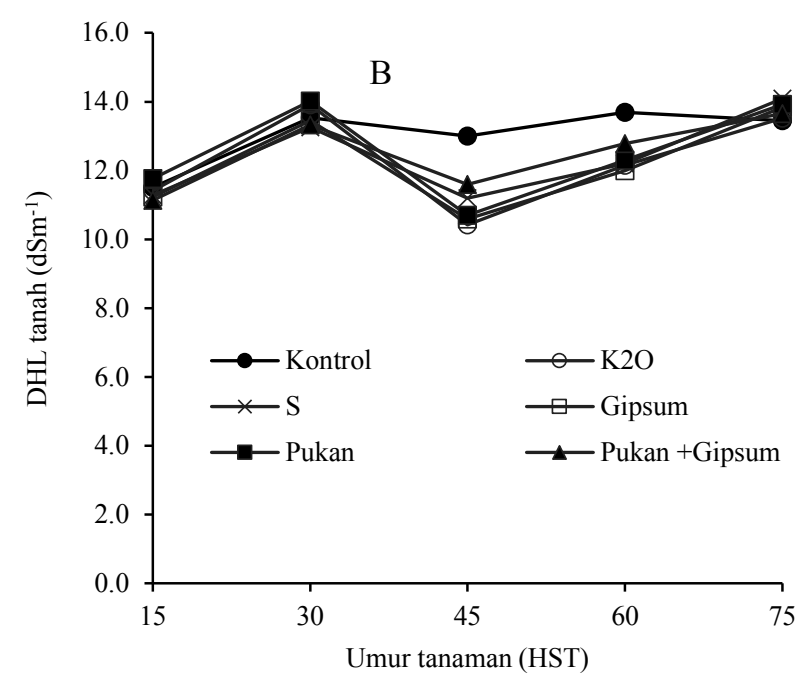

Gambar 1. DHL dan kadar air (KA) tanah (A) serta DHL tanah (B) akibat perlakuan pemulsaan dan ameliorasi pada tanah salin $(\mathrm{M} 0=$ tanpa mulsa, M1 = dengan mulsa) 
Tabel 2. Karakteristik tanah salin saat panen akibat pemulsaan dan ameliorasi

\begin{tabular}{|c|c|c|c|c|c|c|c|}
\hline \multicolumn{2}{|c|}{ Perlakuan } & \multirow{2}{*}{$\begin{array}{c}\mathrm{pH} \\
(1: 5)\end{array}$} & \multirow{2}{*}{$\begin{array}{c}\text { C-org } \\
(\%)\end{array}$} & K-dd & $\mathrm{Na}-\mathrm{dd}$ & Ca-dd & \multirow[t]{2}{*}{ Mg-dd } \\
\hline Pemulsaan & Ameliorasi & & & ........ & $\ldots . . \mathrm{C}$ & $\mathrm{g}^{-1}$ & \\
\hline \multirow[t]{7}{*}{ Tanpa mulsa } & Kontrol & 8.2 & 1.57 & 0.09 & 0.30 & 18.90 & 17.20 \\
\hline & $\mathrm{K}_{2} \mathrm{O}$ & 8.2 & 1.57 & 0.10 & 0.64 & 17.85 & 14.25 \\
\hline & $\mathrm{S}$ & 8.0 & 1.60 & 0.10 & 0.38 & 18.75 & 15.05 \\
\hline & Gipsum & 8.1 & 1.56 & 0.10 & 0.42 & 19.95 & 14.00 \\
\hline & Pukan $^{1)}$ & 8.2 & 1.64 & 0.10 & 0.39 & 19.70 & 15.05 \\
\hline & Gipsum+pukan & 8.1 & 1.72 & 0.10 & 0.35 & 19.85 & 15.60 \\
\hline & Rata-rata & 8.2 & 1.64 & 0.10 & 0.39 & 19.70 & 15.05 \\
\hline \multirow[t]{7}{*}{ Mulsa } & Kontrol & 8.2 & 1.58 & 0.10 & 0.27 & 21.45 & 15.35 \\
\hline & $\mathrm{K}_{2} \mathrm{O}$ & 8.1 & 1.59 & 0.12 & 0.44 & 19.25 & 14.80 \\
\hline & $\mathrm{S}$ & 7.9 & 1.61 & 0.10 & 0.37 & 18.90 & 15.25 \\
\hline & Gipsum & 8.0 & 1.46 & 0.10 & 0.41 & 18.90 & 15.80 \\
\hline & Pukan & 8.2 & 1.58 & 0.11 & 0.47 & 20.80 & 15.70 \\
\hline & Pukan+Gipsum & 8.1 & 1.78 & 0.10 & 0.43 & 21.15 & 15.55 \\
\hline & Rata-rata & 8.1 & 1.60 & 0.11 & 0.40 & 20.08 & 15.41 \\
\hline
\end{tabular}

Keterangan: ${ }^{1)}$ Pukan = pupuk kandang

tanaman umur 75 HST yang lebih tinggi pada pemulsaan dibandingkan tanpa mulsa (Gambar 2). Penggunaan amelioran yang dikombinasikan dengan mulsa berpengaruh positif terhadap IKK tanaman kecuali dengan amelioran gipsum. Apabila amelioran gipsum dikombinasikan dengan pupuk kandang serta dilakukan pemulsaan, dapat meningkatkan IKK tanaman.

Tanaman umumnya mengalami klorosis akibat cekaman salinitas. Kadar garam yang tinggi dapat merusak ultra struktur kloroplas, menurunkan kandungan klorofil dan kuantum enerji pada fotosistem II (Xing et al., 2013; Nokandeh et al., 2015). Penelitian ini menunjukkan bahwa pemulsaan menghambat penurunan kandungan klorofil, yang diduga berkaitan dengan DHL yang lebih rendah pada perlakuan pemulsaan. Penurunan DHL tanah

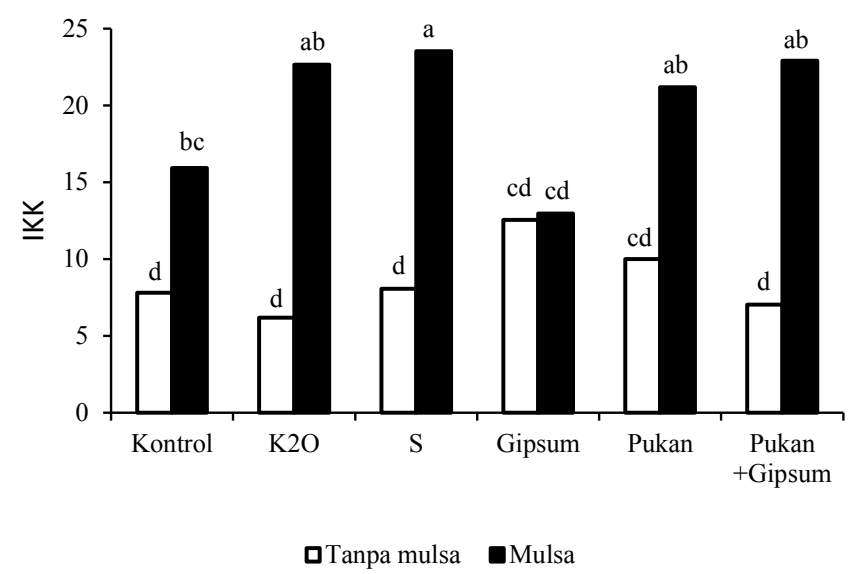

Gambar 2. Indeks kandungan klorofil (IKK) tanaman kedelai umur 75 HST akibat pengaruh mulsa dan amelioran pada tanah salin (huruf yang sama di atas grafik menunjukkan tidak berbeda nyata menurut uji BNT 5\%) serta peningkatan ketersediaan air akibat penggunaan mulsa memberikan kontribusi penting bagi tanaman dalam memperkecil degradasi klorofil daun akibat tingginya salinitas tanah. Penelitian Chen et al. (2015) juga menunjukkan bahwa pemulsaan jerami menurunkan akumulasi garam dan memperbaiki pertumbuhan tanaman.

Dalam penelitian ini, pemberian amelioran $\mathrm{K}_{2} \mathrm{O}, \mathrm{S}$, pupuk kandang dan kombinasi pupuk kandang + gipsum apabila dikombinasikan dengan mulsa jerami mampu mempertahankan IKK pada 75 HST. Hal ini seperti yang dijelaskan Cha-um et al. (2011) dan Shaaban et al. (2013) bahwa penggunaan gipsum dan pupuk kandang menurunkan DHL tanah dan $\mathrm{pH}$ tanah salin, dan mampu menjaga stabilitas klorofil. Lebih lanjut pemulsaan meningkatkan kadar K tanaman 6.85\%, Ca 5.05\%, dan Na tanaman 5.56\% dibandingkan tanpa mulsa, sedangkan nisbah $\mathrm{K} / \mathrm{Na}, \mathrm{Ca} / \mathrm{Na}$ dan $\mathrm{Mg} / \mathrm{Na}$ relatif tidak terpengaruh (Tabel 3). Meskipun $\mathrm{Na}$ tanaman meningkat, tetapi pengaruhnya dapat dikurangi dengan meningkatnya $\mathrm{K}$ dan $\mathrm{Ca}$. Hingga tanaman berumur 45 HST, kandungan air tanah pada perlakuan pemulsaan cenderung lebih tinggi dibandingkan tanpa mulsa, dan hal ini akan meningkatkan penyerapan $\mathrm{K}, \mathrm{Ca}$, dan $\mathrm{Na}$. Kecenderungan IKK yang lebih tinggi pada perlakuan pemulsaan maupun kombinasi antara pemulsaan dengan ameliorasi, selain karena penurunan DHL tanah, juga karena peningkatan kadar $\mathrm{K}$ dan $\mathrm{Ca}$ tanaman.

\section{Hasil dan Komponen Hasil}

Pemulsaan dan ameliorasi berpengaruh terhadap jumlah polong isi dan hasil biji. Hasil biji dengan pemulsaan $15.3 \%$ cenderung lebih tinggi dibandingkan tanpa mulsa, dan berdasarkan uji BNT $10 \%$ pemberian amelioran cenderung meningkatkan jumlah polong isi dan hasil biji 
Tabel 3. Kandungan K, Na, Ca dan Mg tanaman kedelai fase berbunga (fase R1)

\begin{tabular}{|c|c|c|c|c|c|c|c|c|}
\hline \multirow{2}{*}{ Pemulsaan } & \multirow{2}{*}{ Ameliorasi } & $\mathrm{K}$ & $\mathrm{Na}$ & $\mathrm{Ca}$ & $\mathrm{Mg}$ & $\mathrm{K} / \mathrm{Na}$ & $\mathrm{Ca} / \mathrm{Na}$ & $\mathrm{Mg} / \mathrm{Na}$ \\
\hline & & \multicolumn{7}{|c|}{, } \\
\hline \multirow[t]{7}{*}{ Tanpa mulsa } & Kontrol & 5.54 & 1.12 & 1.06 & 0.61 & 4.9 & 0.95 & 0.54 \\
\hline & $\mathrm{K}_{2} \mathrm{O}$ & 5.55 & 1.22 & 0.96 & 0.60 & 4.5 & 0.79 & 0.49 \\
\hline & $\mathrm{S}$ & 3.91 & 0.91 & 0.93 & 0.60 & 4.3 & 1.02 & 0.66 \\
\hline & Gipsum & 5.83 & 1.22 & 1.09 & 0.61 & 4.8 & 0.89 & 0.50 \\
\hline & Pukan $^{1)}$ & 4.89 & 1.02 & 0.98 & 0.59 & 4.8 & 0.96 & 0.58 \\
\hline & Pukan + Gipsum & 4.92 & 1.01 & 0.93 & 0.59 & 4.9 & 0.92 & 0.58 \\
\hline & Rata-rata & 5.11 & 1.08 & 0.99 & 0.60 & 4.7 & 0.92 & 0.56 \\
\hline \multirow[t]{7}{*}{ Mulsa } & Kontrol & 5.84 & 1.15 & 0.96 & 0.58 & 5.1 & 0.83 & 0.50 \\
\hline & $\mathrm{K}_{2} \mathrm{O}$ & 5.28 & 1.08 & 1.07 & 0.59 & 4.9 & 0.99 & 0.55 \\
\hline & $\mathrm{S}$ & 5.33 & 1.14 & 1.04 & 0.61 & 4.7 & 0.91 & 0.54 \\
\hline & Gipsum & 5.30 & 1.14 & 1.04 & 0.59 & 4.6 & 0.91 & 0.52 \\
\hline & Pukan & 5.62 & 1.17 & 1.05 & 0.57 & 4.8 & 0.9 & 0.49 \\
\hline & Pukan+Gipsum & 5.41 & 1.14 & 1.07 & 0.59 & 4.7 & 0.94 & 0.52 \\
\hline & Rata-rata & 5.46 & 1.14 & 1.04 & 0.59 & 4.8 & 0.91 & 0.52 \\
\hline
\end{tabular}

Keterangan: ${ }^{1)}$ Pukan = pupuk kandang

(Tabel 4). Ameliorasi dengan gipsum memberikan hasil biji paling tinggi yang didukung oleh jumlah polong isi per tanaman yang paling banyak pula; disamping itu pemulsaan cenderung meningkatkan ukuran biji $20 \%$ dibandingkan tanpa pemulsaan. Lebih tingginya hasil biji akibat pemulsaan maupun akibat ameliorasi dengan gipsum mungkin karena pertumbuhan yang lebih baik disebabkan oleh pemulsaan yang menurunkan DHL, dan gipsum menurunkan DHL dan $\mathrm{pH}$ tanah. Indeks panen sangat rendah (sekitar 0.2), menunjukkan partisi fotosintat ke biji rendah. Gejala visual yang jelas terlihat adalah pertumbuhan kerdil, daun mengalami klorosis dan cepat gugur, sehingga aktivitas fotosintesis terganggu. Hasil penelitian Cabot et al., (2014) menunjukkan bahwa cekaman salinitas menyebabkan terjadinya penuaan daun lebih cepat sehingga menurunkan hasil. Menurut Bustingorri dan Lavado (2011) pada DHL $4 \mathrm{dS} \mathrm{m}^{-1}$ terjadi penurunan hasil kedelai hingga $80 \%$, dan tanaman kedelai tidak pernah mencapai fase reproduksi pada DHL $8 \mathrm{dS} \mathrm{m}^{-1}$.

Hasil kedelai berkorelasi negatif dengan DHL tanah dengan pola penurunan linier $\mathrm{Y}=4.2521-0.2674 \mathrm{X}$, dengan Y adalah hasil biji dan X adalah DHL tanah (Gambar 3A). Hal ini menunjukkan bahwa pada tanah salin, penurunan DHL menjadi faktor penentu peningkatan hasil kedelai. Penurunan DHL tersebut dapat dilakukan dengan pemulsaan atau ameliorasi tanah dengan gipsum. Berdasarkan sebaran

Tabel 4. Keragaan tanaman dan hasil kedelai pada tanah salin saat panen

\begin{tabular}{|c|c|c|c|c|}
\hline Perlakuan & $\begin{array}{l}\text { Jumlah polong isi } \\
\text { per tanaman }\end{array}$ & $\begin{array}{l}\text { Hasil biji } \\
\left(\mathrm{kg} \mathrm{ha}^{-1}\right)\end{array}$ & $\begin{array}{l}\text { Bobot } 100 \text { biji } \\
(\mathrm{g})\end{array}$ & Indeks panen \\
\hline \multicolumn{5}{|l|}{ Mulsa } \\
\hline Tanpa mulsa & 16 & 850 & $11.21 \mathrm{~b}$ & 0.23 \\
\hline Mulsa & 17 & 980 & $13.56 \mathrm{a}$ & 0.24 \\
\hline \multicolumn{5}{|l|}{ Ameliorasi } \\
\hline Kontrol & $14 b *)$ & $800 \mathrm{~b} *)$ & 12.45 & 0.23 \\
\hline $\mathrm{K}_{2} \mathrm{O}$ & $17 \mathrm{ab}$ & $960 \mathrm{ab}$ & 12.76 & 0.23 \\
\hline $\mathrm{S}$ & $17 \mathrm{ab}$ & $830 \mathrm{~b}$ & 11.86 & 0.22 \\
\hline Gipsum & $19 a$ & $1,090 \mathrm{a}$ & 12.39 & 0.24 \\
\hline Pupuk kandang & $15 b$ & $850 \mathrm{~b}$ & 12.41 & 0.25 \\
\hline Pukan+Gipsum & $16 a b$ & $930 \mathrm{ab}$ & 12.46 & 0.24 \\
\hline
\end{tabular}

Keterangan: *)Angka dengan huruf yang sama atau tanpa didampingi huruf pada kolom di masing-masing kelompok perlakuan menunjukkan tidak berbeda nyata dengan uji BNT taraf $10 \%$ 

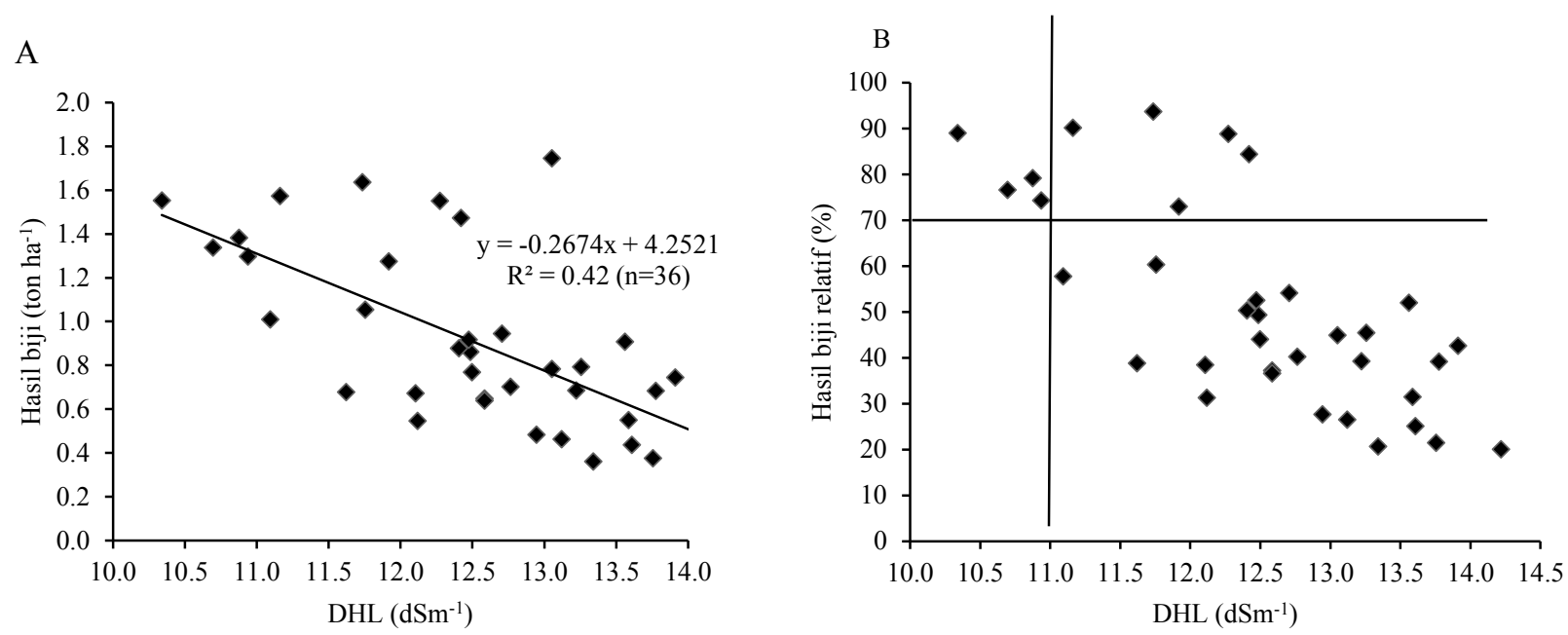

Gambar 3. Hubungan DHL tanah dengan hasil biji (A) dan dengan hasil relatif biji (B) pada galur kedelai K-13 di tanah salin

hubungan hasil biji relatif dengan DHL terlihat bahwa penurunan hasil kedelai $30 \%$ (hasil relatif $70 \%$ ) terjadi pada DHL sekitar $11 \mathrm{dS} \mathrm{m}^{-1}$, dan penurunan hasil menjadi $>30 \%$ pada DHL $>11 \mathrm{dS} \mathrm{m}^{-1}$ (Gambar 3B). Berdasarkan penurunan hasil relatif $30 \%$, DHL tanah tertinggi yang dapat ditolerir oleh galur K-13 adalah DHL $11 \mathrm{dSm}^{-1}$. Dengan demikian, penanaman kultivar toleran salin juga menjadi faktor penentu keberhasilan budidaya kedelai pada lahan salin.

\section{KESIMPULAN}

Penggunaan mulsa menurunkan DHL tanah, meningkatkan penyerapan unsur $\mathrm{K}$ dan $\mathrm{Ca}$, serta meningkatkan indeks kandungan klorofil serta memperbaiki pertumbuhan dan hasil kedelai yang toleran salin. Ameliorasi tanah menggunakan $\mathrm{K}_{2} \mathrm{O}$, belerang $(\mathrm{S})$, gipsum, serta kombinasi pupuk kandang+gipsum menurunkan DHL dan $\mathrm{pH}$ tanah. Ameliorasi dengan gipsum meningkatkan hasil biji kedelai toleran salin hingga 36.3\%. Penurunan DHL menjadi faktor penentu keberhasilan budidaya kedelai di lahan salin dengan pemulsaan atau dengan ameliorasi tanah serta penanaman kultivar toleran salin.

\section{DAFTAR PUSTAKA}

Abou-Baker, N.H., M. Abd-Eladl, M.M.Abbas. 2011. Use of silicate and different cultivation practices in alleviating salt stress effect on bean plants. Aus. J. Basic Appl. Sci. 5:769-781.

Alharbi, A. 2015. Effect of mulch on soil properties under organic farming conditions in center of Saudi Arabia. J. Am. Sci. 11:108-115.

Alihamsyah,T., M. Sarwani, I. Ar-Riza. 2002. Lahan pasang surut sebagai sumber pertumbuhan produksi padi masa depan. hal. 263-287. Dalam B. Suprihatno, A.K.
Makarim, I.W. Widiarta, Hermanto, dan A.S. Yahya $(E d s)$. Kebijakan Perberasan dan Inovasi Teknologi Padi. Buku 2. Pusat Penelitian dan Pengembangan Tanaman Pangan, Bogor.

Bustingorri, C., R.S. Lavado. 2011. Soybean growth under stable versus peak salinity. Sci. Agric. (Piracicaba, Braz.). 68:102-108.

Cabot, C., J.V. Sibole, J. Barcelo, C. Poschenrieder. 2014. Lessons from crop plants struggling with salinity. Plant Sci. 226:2-13.

Cha-um, S., Y. Pokasombat, C. Kirdmanee. 2011. Remediation of salt-affected soil by gypsum and farmyard manure-Importance for the production of jasmine rice. Aust. J. Crop Sci. 5:458-465.

Chen, X., Y. Kang, S. Wan, X. Li, L. Guo. 2015. Influence of mulches on urban vegetation construction in coastal saline land under drip irrigation in North China. Agric. Water Manag. 158:145-155.

Dogar, U.F., N. Naila, A. Maira, A. Iqra, I. Maryam, H. Khalid, N. Khalid, H.S. Ejaz, H.B. Khizar. 2012. Noxious effects of $\mathrm{NaCl}$ salinity on plants. Botany Res. Inter. 5:20-23.

Dong, H. 2012. Technology and field management for controlling soil salinity effects on cotton. Aust. J. Crop Sci. 6:333-341.

Erfandi, D., A. Rachman. 2011. Identification of soil salinity due to sea water intrusion on rice field in the Northern Coast of Indramayu, West Java. J. Tropical Soils. 16:115-121. 
Gharaibeh, M.A, N.I. Eltaif, S.H. Shra'ah. 2011. Leaching curves of highly saline-sodic soil amended with phosphoric acid and phosphogypsum. $2^{\text {nd }}$ International Conference on Agricultural and Animal Science. IPCBEE Vol. 22. IACSIT Press, Singapore, SG.

Golezani, K.G., M.T Noori, S. Oustan, M. Moghaddam, S.S Rahmani. 2011. Physiological performance of soybean cultivars under salinity stress. J. Plant Physiol. Breeding 1:1-7.

Joachim, H.J.R.M., H. Verplancke. 2010. Effect of gypsum placement on the physical chemical properties of a saline sandy loam soil. Aust. J. Crop Sci. 4:556-563.

Kahlon, U.Z., G. Murtaza, A. Ghafoor. 2012. Amelioration of saline-sodic soil with amendments using brackish water, canal water and their combination. Int. J. Agric. Biol. 14:38-46.

Kopittke, P.M. 2012. Interactions between $\mathrm{Ca}, \mathrm{Mg}, \mathrm{Na}$ and $\mathrm{K}$ : alleviation of toxicity in saline solutions. Plant Soil 352:353-362.

Kusmiyati, F., Sumarsono, Karno. 2014. Pengaruh perbaikan tanah salin terhadap karakter fisiologis Calopogonium mucunoides. Pastura 4:1-6.

Mahdy, A.M. 2011a. Comparative effects of different soil amendments on amelioration of saline-sodic soil. Soil Water Res. 6:205-216.

Mahdy, A.M. 2011b. Soil properties and wheat growth and nutrients as affected by compost amendment under saline water irrigation. Pedosphere 21:773-781.

Murtaza, G., B. Murtaza, H.M. Usman, A. Ghafoor. 2013. Amelioration of saline-sodic soil using gypsum and low quality water in following sorghum-berseem crop rotation. Inter. J. Agric. Biol. 15:640-648.

Nazar, R., N. Iqbal, A. Masood, Sh. Syeed, N.A. Khan. 2011. Understanding the significance of sulfur in improving salinity tolerance in plants. Environ. Exp. Bot. 70:80-87.

Nokandeh, S.E., M.A. Mohammadian, B. Damsi, M. Jamalomidi. 2015. The effect of salinity on some morphological and physiological characteristics of three varieties of (Arachis hypogaea L.). Inter. J. Adv. Biotechnol. Res. 6:498-507.
Purwaningrahayu, R.D., A. Taufiq. 2017. Respon morfologi empat genotipe kedelai terhadap cekaman salinitas. J. Biologi Indonesia 13:175-188.

Purwaningrahayu, R.D., H.T. Sebayang, Syekhfani, N. Aini. 2015. Resistance level of some soybean (Glycine $\max$ L. Merr) genotypes toward salinity stress. J. Biol. Res. 20:7-14.

Rachman, A., D. Erfandi, M.N. Ali. 2008a. Dampak tsunami terhadap sifat-sifat tanah pertanian di NAD dan strategi rehabilitasinya. J. Tanah Iklim. 28:27-38.

Rachman, A., I.G.M. Subiksa, D. Erfandi, P.Slavich. 2008b. Dynamics of tsunami-affected soil properties. p. 51-64. In F. Agus, G. Tinning (Eds). Proc. of Inter. Workshop on Post Tsunami Soil Management.

Shaaban, M., M. Abid, R.A.I. Abou-Shanab. 2013. Amelioration of salt affected soils in rice paddy system by application of organic and inorganic amendments. Plant Soil Environ. 59:227-233.

Sunarto. 2001.Toleransi kedelai terhadap tanah salin. Bul. Agron. 29:27-30.

Swarup, A. 2013. Sustainable management of salt-affected soils and poor-quality of ground waters for enhanching crop production. P. 327-334. In S.A. Shahid, M.A. Abdelfattah, F.K. Taha (Eds.). Development in Soil Salinity Assesment and Reclamation: Innovative Thinking and Use of Marginal Soil and Water Resources in Irrigated Agriculture. Springer Sci. And Busines, Dordrecht, NL.

Tazeh, E.S, E. Pazira, M.R. Neyshabouri, F. Abbasi, H.Z. Abyaneh. 2013. Effects of two organic amendments on EC, SAR and soluble ions concentration in a saline sodic soil. Inter. J. Biosci. 3:55-68.

Xing, W., J. Wang, H. Liu, D. Zou, H. Zhao. 2013. Influence of natural saline-alkali stress on chlorophyll content and chloroplast ultra structure of two contrasting rice (Oryza sativa L. japonica) cultivars. Aust. J. Crop Sci. 7:289-292.

Zhang, Q.T., M. Inoue, K. Inosako, M. Irshad, K. Kondo, G.Y. Qiu, S. P. Wang. 2008. Ameliorative effect of mulching on water use efficiency of Swiss chard and salt accumulation under saline irrigation. J. Food, Agric. Environ. 6:480-485. 